\title{
Impact of Self-Directed Learning and Educational Technology Readiness on Synchronous E-Learning
}

\author{
Ka Yin Chau, Faculty of Business, City Univeristy of Macau, Macao \\ iD https://orcid.org/0000-0002-0381-8401 \\ Kris M. Y. Law, Deakin University, Australia \\ iD https://orcid.org/0000-0003-3659-0033 \\ Yuk Ming Tang, Department of Industrial and Systems Engineering, The Hong Kong Polytechnic University, Hong Kong \\ (iD) https://orcid.org/0000-0001-8215-4190
}

\begin{abstract}
COVID-19 has had severe global impacts in many aspects of education. Asian countries and regions were the first to move entirely online. The aim of this paper is two-fold. First, this study investigates the correlations in order to understand the compound effects on presences in the participating synchronous learning environments. Second, this paper provides empirical evidence and insights for educators on the future trends of learning and instructional strategy in online teaching. This study investigated students' perceptions of synchronous e-learning during the COVID-19 pandemic for the better design of the e-learning teaching pedagogy and determines how the key factors of e-learning perception are inter-correlated. The study has important implications on student readiness in educational technology, which is critical to implementing online learning.
\end{abstract}

\section{KEYWORDS}

COVID-19 Pandemic, E-Learning, Self-Directed Learning, Students' Perception, Synchronous Learning, Technology Readiness

\section{INTRODUCTION}

As the pandemic has shut down the physical world, there is a general assumption that the digital world will step in to fill the gap. It is unavoidable that the higher education sector must respond to the pandemic by introducing more online components or transiting to the complete online mode. Asian countries and regions have rapidly moved completely online since the epidemic started worldwide. Courses with online teaching and learning have been offered in Hong Kong universities since late January 2020, at the beginning of the outbreak. This study was carried out in response to the global COVID-19 pandemic, which forced universities to change from face-to-face (FTF) learning to synchronous learning.

Online learning is an alternative to classroom teaching by engaging technology and facilitating learning environments online (Rovai and Jordan, 2004). With the mostly autonomous structure, the online curriculum offers students more flexibility in deciding how and time for participation (Milligan and Littlejohn, 2014). There are various approaches to adopting the latest computer technologies to 
support students' online learning, including MOOC, problem-based learning (Mo \& Tang, 2107), blended learning, flipped classroom, and mobile learning (Tang \& Yu, 2018). However, many students are overwhelmed by these new learning technologies and the one thing in common that they support mainly asynchronous learning. Despite synchronous and asynchronous learning being used by educators for many years (Francescucci \& Rohani, 2019), the adoption of synchronous learning increased dramatically during the pandemic, as it was the only way to continue delivering classes during the COVID-19 outbreak.

Synchronous learning refers to online or distance education in real-time and students participate in scheduled classes as they did in normal FTF learning. Unlike normal learning, synchronous learning requires students to log in and participate online (Mehri \& Uplane, 2015; Hrastinski, 2008). In contrast, asynchronous learning adopts computers or mobile devices to facilitate the sharing of online learning resources and information and promote peer-to-peer communications and interactions. Asynchronous online learning eliminates spatial constraints to enable students to learn anytime and anywhere. For instance, Holenko et al. (2020) adopted synchronous mobile computer-supported technology for supporting collaborative student learning. Martin \& Parker (2014) used virtual classrooms to allow communication between students and educators synchronously, with the classroom providing several key functions, including audio, video, chatbox, whiteboard, information sharing, etc.

Despite both synchronous and asynchronous learning approaches being implemented for students' online learning, synchronous learning has been more widely adopted in Asian countries and regions during the COVID-19 pandemic. The approaches require student self-participation and study to facilitate learning, unlike regular education. Although there are various computer technologies to support synchronous learning, the effects of computer-assisted technology on students' perception of participating in online synchronous learning, especially during the COVID-19 pandemic, still need to be investigated.

This paper explores the correlations between learning attributes in student motivation, selfdirected learning, and readiness in using technologies to assist in online learning and their combined effects on the perceived synchronous learning environment. Furthermore, considering the pandemic situation due to the coronavirus outbreak since early 2020 , this study aims to give empirical evidence and insights for educators for future trends in learning and instructional strategies in online teaching. This study has two major impacts: (1) the study is significant to the education sector in the design and development of new teaching pedagogies for students to participate in online learning; (2) the study is significant to the supporting industries in the design and development of teaching and learning materials such as STEM tools, books, etc., as well as the equipment and software for supporting online learning. Lastly, some of the latest technologies that can be used to support further teaching and training activities are investigated in the discussion section.

\section{LITERATURE REVIEW}

\subsection{Online Learning Technologies}

Nowadays, due to the era of digital technologies and the popularity of mobile devices, the need for online learning is exponentially increasing. On the other hand, the Massive Open Online Course (MOOC) (You, 2019) and eLearning have become hugely popular due to their higher flexibility, convenience, and focus on the need of individual learners compared with traditional face-to-face courses (Bolsen, 2016). Resources for Online Learning include electronic materials, videos, recorded lectures, quizzes, discussion forums, live teaching, etc. (Jelfs, 2013).

Many different technologies and tools exist for supporting online teaching and learning, such as virtual reality (VR), artificial intelligence (AI), Internet of Things (IoT), learning management system (LMS), cloud computing, etc. (Qurat-ul-Ain, 2019). Learning technologies, online learning platforms enable the effective transition of learning activities to support asynchronous and cooperative learning. 
Effective facilitation for online learning is necessary as students always look for feedback like they used to receive in a face-to-face class setting (Vanslambrouck et al., 2018). Tang et al. (2018 and 2020) adopted mixed reality (MR) for teaching product design in higher education. Liu et al. (2019) compared the augmented reality (AR) with physical experiments for product innovation. The use of VR/ AR/ MR is not the only technology that can enhance students' motivation and effectiveness. Pervez et al. (2018) investigated the role of the Internet of Things Technologies in higher education. Different e-learning approaches and the impact of the Internet of Things and big data analytics applied to the e-learning area are reviewed in Kusuma \& Viswanath (2018). The adoption of effective educational technology for online learning has been studied (Findik \& Ozkan, 2013; Mtebe \& Raisamo, 2014). However, it is challenging to design practical online courses, particularly in providing flexibility during teaching, facilitating motivation and enhancing students' learning process, and fostering effective learning (Boelens et al., 2017).

Different factors influence students' learning experience undertaking online learning compared with traditional teaching approaches (Vaughan, 2007; Tabor, 2007). Ni (2013) compared the effectiveness of conventional classroom teaching and students' online learning. Student's grading and the quality and quantity of interaction were measured. The quality of the interactions was measured based on the communication, and the degree of learner-centricity in the teaching and learning process (Baig, 2011). Online learning, particularly synchronous learning, very much relies on support from computer technologies. The effective adoption of internet technology components determines learning effectiveness (Garrison \& Kanuka, 2004). Technology readiness is one of the measurement factors relating to student learning efficiency. Students nowadays are more familiar with using digital products, and the latest emergence of computer technologies enables the teaching to be conducted using multimedia materials and communications online (Prensky, 2001; Horton, 2006). Studies have been carried out on understanding the determinant factors of online learning (Liu \& Carlsson 2010; Wang \& Wang 2009). These factors include the readiness of e-learning, which refers to the intention of using new technologies for participating in learning (Parasuraman, 2000; Piskurich, 2003; Moftakhari, 2013). However, the student technology efficacy and readiness in e-learning motivation and perception, particularly in synchronous teaching mode, have seldom been studied. This further information and investigation are important bases for educators to decide on the strategy and pedagogy for e-learning.

\subsection{Synchronous Learning}

Online learning or synchronous learning is an alternative to classroom teaching by engaging technology and facilitative learning environments online (Rovai and Jordan, 2004; Law, 2019, Law et al., 2019). The online curriculum offers students a high level of flexibility in learning engagement (Milligan and Littlejohn, 2014). However, this requires self-monitoring and awareness of their responsibility in the learning process (Zimmerman, 2000). A self-directed student can proactively engage in the learning processes (Phalaunnaphat, 2015; Yilmaz, 2016). The three co-existing presences in the Community of Inquiry $(\mathrm{CoI})$ theoretical framework represents a process of creating social and intellectual interactions, and meaningful learning experience. These presences, social, cognitive, and teaching, promote the interactions of participants with the teaching materials (Garrison \& Cleveland-Innes, 2005; Annand, 2011). Among these presences, social presence and teaching presence are often used to assess students' learning experience and effectiveness. However, research on explaining the impact of technologyenhanced learning and its learning outcome is still limited (Gulek and Demirtas, 2005; Sana, Weston, and Cepeda, 2013). Hence, it is worthwhile to explore their technology readiness and individual attributes, such as motivation and academic performance in the synchronous learning context.

\subsubsection{Perception of Learning Presences}

Regarding learning effectiveness, to be specific, student performance factors such as motivation and other individual learning presences are considered in many studies. Student learning presences 
such as social presence and teaching presence are tightly interconnected (Shea et al., 2010). Student perceptions of social presence and teaching presence, according to the CoI theory, reveal the learning experience of students (Richardson et al., 2012). Social presence refers to the capacity of learners to present themselves with individual characteristics and their ability to help form personal relationships (Wei et al., 2012). It is defined as the student's communication and social abilities and describes the sense of physical and relational closeness during communication (Short et al., 1976).

Teaching presence affects the design, facilitation, and direction of cognitive and social processes to realize personally meaningful and educationally worthwhile learning outcomes (Kim \& Song, 2021). Teaching presence drives the student to actively think and engage, whereas social presence refers to learners' social and emotional behaviour (Hwang and Arbaugh, 2006). However, the interrelationship between social presence and teaching presence has not been considered in a purely online learning setting, and therefore, requires further exploration.

The theory of planned behaviour (TPB) and the social cognitive theory (SCT) indicate that technology readiness and self-directed learning motivate students to behave according to different perceptions and learning experiences (Ajzen, 1991; Compeau \& Higgins, 1995). On the other hand, students' directed learning relates to motivation in learning independently, a sense of responsibility, and the initiative in learning (Broadbent, 2017; Geng et al., 2019).

\subsubsection{Self-Directed Learning}

Self-directed learning (SDL) refers to learners' direct understanding of the knowledge and setting goals (Gilbert \& Driscoll, 2002; Lee \& Teo, 2010; Geng et al., 2019). SDL contributes to the adoption of e-learning and collaborative learning (Lee et al., 2014). Studies on self-directed learning with technology (SDLT) revealed that collaborative learning could enhance a student's SDL. It was also revealed that learners skilled at SDL engaged in learning more frequently (Kizilcec et al., 2017).

\subsubsection{Learning Motivation}

The learning motivation of a student involves two significant concepts: intrinsic and extrinsic motivation. Intrinsic motivation is the enjoyment of the engaged task or a sense of fulfilment an individual acquires from engaging in an activity dealing with interest and curiosity. Intrinsic motivation usually encourages a student to voluntarily perform a task without rewards (Amirkhanova et al., 2016). In contrast, extrinsic motivation refers to the student's willingness and motivation to achieve a task or a goal with external benefits or rewards (Riswanto \& Aryani, 2017). Students' learning motivation is particularly important to drive their presence in class and a willingness to participate and interact in class, while students with no strong motivation of learning are likely to learn very little in class and generally feel the class activities are painful and frustrating (Filogna et al., 2020).

\subsubsection{Technology Readiness}

Technology readiness relates to the willingness to apply new technologies, which vary between individuals (Parasuraman, 2000). Technology readiness usually refers to computer-assisted technologies such as VR, 3D printing (Mo \& Tang, 2017), AI, as well as the use of other learning platforms, including zoom, MS Teams, LMS, etc. Technology not only enables information to be shared between peers and educators, but it is also essential for effective communication in distance education (Faisal \& Kisman, 2020). Therefore, it is essential to investigate student perception of teaching and learning, particularly online learning, as it affects students' abilities in effective individual and group communication, access and sharing of materials, etc. (Tang et al., 2021). The Technology Readiness Index (TRI), consisting of 28 items, was developed for measuring technology readiness (Parasuraman, 2000). These 28 items are clustered into four categories, reflecting the individual attitude toward the acceptance of the latest technologies in their learning process. 


\subsection{Research Questions}

The coronavirus outbreak offers an unprecedented opportunity for online learning. It is inevitable for universities to transition from different modes of learning to online learning. Under the current situation, it is obvious that students learning is affected by external effects. Therefore, this research is based on the theory on the behaviourism learning theory that how a student behaves in the physical and virtual classes is based on environmental factors (Bryant et al., 2013). Certain external factors influence student's behaviours in their learning. At the same time, it is believed that the coronavirus outbreak is the external force that pushes students' learning motivation, self-directed learning, as well as their technology readiness.

Online teaching and learning are believed to become a new norm of many universities and schools globally. Despite previous research that has been conducted to investigate the online teaching and learning pedagogy, the existing research is not dealing with the entire shift of normal face-to-face class teaching to the synchronous mode of teaching. It is valuable to explore how this external factor (i.e., pandemic situation) affects students learning attitude and learning attitudes. The exploration of the impacts of SDL and technological readiness on the perceptions of learning presence is crucial in understanding student behaviour in an online learning environment. Therefore, this study poses the following research question (RQ): Are self-directed learning (SDL) and technology readiness the critical determinants influencing learning in an online setting?

\section{METHODOLOGY}

\subsection{Research Hypotheses}

A proposed hypothesised model is shown in Figure 1 to illustrate the relationships between SDL, motivation, readiness in technology, and student's perception of online learning.

\subsubsection{Impacts of $S D L$}

Self-directed learners impose significant repercussions in learning effectiveness, as they proactively engage in the learning process (Tullis \& Benjamin, 2011). Vibrant online learning content enables students to have greater flexibility and opportunity to adopt SDL (Geng et al., 2019). Self-directed learners usually have more initiative to participate in online learning, with higher definite intentions to achieve learning goals. The role of self-directed learning was revealed to have a positive relationship with the Community of Inquiry (CoI) framework (Garrison \& Akyol, 2013). In addition, SDL is related to self-motivation to enhance learning by adopting different strategies to achieve study goals (Khalid et al., 2020). Hence, we hypothesise that:

H1. Self-directed learning (SDL) positively impacts on the perception of learning presences H2. Self-directed learning (SDL) positively impacts on learning motivation (LM)

\subsubsection{Technology readiness}

Technology readiness is usually influenced by users motivation in the adoption of service, particularly in the online market and other smart services (Chang \& Chen, 2021). Students with higher technology readiness levels are more willing to participate in online learning (Parasuraman \& Colby, 2015; Geng et al., 2019). Student perceptions of learning technologies reflect their technology readiness and influence the intention and motivation to positively adopt online learning and outcomes (Cheon et al., 2012; Hong et al., 2014). Therefore, we hypothesise that:

H3. Technology readiness (TRD) of students positively impacts on the perception of learning presence H4. Technology readiness (TRD) of students positively influences the learning motivation (LM) 


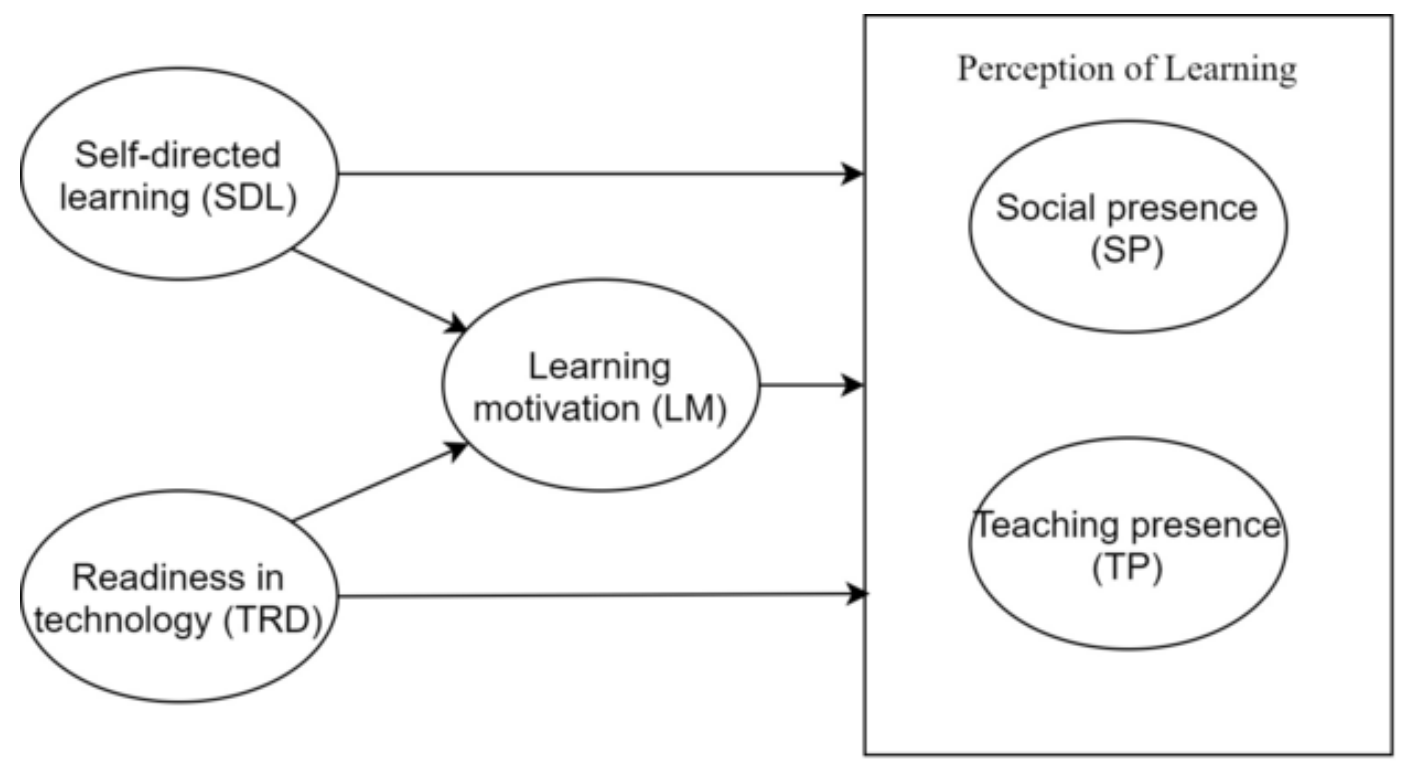

\subsubsection{Impacts of learning motivation}

Students who have stronger motivation in online learning are more likely to possess online learning material (Law et al., 2010), which significantly affects the learning effectiveness. However, the relationships between learning motivation, self-directed learning, and technology readiness in the online learning context have not been sufficiently explored. Motivation is a goal-directed activity essential in both online and face-to-face learning (Fredricks et al., 2004; Law et al., 2017). According to Tan (2021), learning motivation shows a strong correlation among three constructs of the community of inquiry and performance. Furthermore, Law et al. (2019) suggest that student enrolment and motivation are positively related to the effects of social, teaching, and cognitive presence in a blended learning environment. Therefore, we hypothesise that:

H5. Learning motivation (LM) of students positively impacts on the learning presences

\subsection{Data Collection}

Online learning courses were offered in universities in Hong Kong, during the outbreak of COVID-19, in late January 2020. Three institutes in the Hong Kong higher education sector, covering six subjects participated in this study. The survey was conducted 2-3 weeks after the commencement of online teaching so that students could have sufficient time to experience online learning and provide quality feedback to the study. The survey was distributed to the students during breaks or after the lesson. Students participated in the study voluntarily, and informed consent was obtained.

\subsection{Instrument}

A questionnaire that consisted of two parts concerning previous studies was employed as the instrument of data collection. A 5 point Likert scale was used for measurement. The first part contains four components (corresponding to the factors of the model shown in Figure 1). In total, there were 44 questions used in this study, in which 8 questions were used to determine learning motivation and 
technology readiness scales, and 10 questions were used to measure the self-directed learning scale. The learning presences consist of 10 questions for measuring the social presence and teaching presence:

1) Learning motivation scale (Tang et al., 2021; Geng et al., 2019)

2) SDL with the support of technology (Tang et al., 2021; Geng et al., 2019; Lee et al., 2014) for measuring the perception of self-directed learning supported by technology.

3) Students' technological readiness in a learning platform (Tang et al., 2021; Parasuraman \& Colby, 2015), the propensity to adopt new technologies in learning (Geng et al., 2019).

4) Modified learning presence, based on the $\mathrm{CoI}$ instrument identifying teaching presence, social presence in a learning environment (Tang et al., 2021; Law et al., 2019a; Geng et al., 2019).

The second part concerned the respondent's particulars. A pilot study was also performed among a group of university lecturers offering synchronous courses during the COVID-19 outbreak in Hong Kong, to confirm the validity of the questionnaire.

\subsection{Measurement Model Estimation}

Statistical analysis of the proposed model was performed by using Partial Least Squares (PLS) (Henseler \& Sarstedt, 2013) (Figure 1). The Cronbach's reliability and Average Variance Extracted (AVE) were then used to verify the measurement variables in the hypothesized model. For all variables, the Cronbach's reliability and the AVE values of over 0.70 (Sanchez, 2013) and above 0.40 (Tang, 2021) were used as the acceptable values respectively. The factor loading results higher than 0.6 were required. On the other hand, the square root of the AVE for each measurement item larger than its correlation with another variable was used to validate the discriminant validity condition (Chin 1998).

\section{RESULTS}

\subsection{Demographics information}

In this study, 500 engineering students from three universities were invited to participate in the survey study, and a total of 372 valid samples were returned. The demographic details of the collected survey are illustrated in Table 1 . There were $43.54 \%$ males and $56.46 \%$ females who participated in synchronous learning, in which over $90 \%$ of them were aged 24 or below. There were $29.30 \%$ of students studying at the master's degree level, while $28.49 \%$ and $42.20 \%$ were studying at the undergraduate's degree and sub-degree levels. Interestingly, even though many students were studying at the master's degree level, most of them were below 24. The results obtained from One-way ANOVA revealed that the parameter gender groups do not show a significant difference.

\subsection{Reliability and Convergency Tests}

As illustrated in Table 2, the Cronbach's reliability and the AVE values for all variables were over 0.70 and above the acceptable value of 0.40 respectively. Therefore, the measurement dimensions fulfilled the requirements in both the reliability and validity tests.

Table 3 presents the factor loadings results, which show convergent validity of higher than 0.6. On the other hand, the square root of the AVE for each measurement item was larger than its correlation with another variable, so the discriminant validity condition was fulfilled (Table 4) (Chin 1998). Based on the results in table 4, it was revealed that the measurement variables showed a high positive correlation between each other at the significance level of 0.01 .

\subsection{Surveyed Items}

The overall descriptive results of the 5 measurement variables are illustrated in Table 5. The results showed that the mean scores were between 3.29 to 3.59, where learning motivation, technology 
Table 1. Details of demographic information of the collected survey

\begin{tabular}{|l|l|l|}
\hline & & Total \\
\hline Gender & Male & 162 \\
\hline & Female & 210 \\
\hline Age & 24 or below & 336 \\
\hline Degree & Above 24 & 36 \\
\hline & Master or above & 109 \\
\hline & Undergraduate & 106 \\
\hline Total & Sub-degree & 157 \\
\hline
\end{tabular}

readiness, and teaching presence showed a higher score than social presence and self-directed learning in general.

Independent sample t-testing was carried out to investigate the difference between the gender groups. The results illustrated in Table 6 show that only technology readiness and learning motivation had a significant difference at the level of 0.05 between males and females.

\subsection{PLS Path Modelling}

The relationship between each measurement variable and item and the research model are presented in Figures 2 and 3, graphically. The corresponding statistical analysis with both direct and indirect relationships was determined and is presented in Table 7. All path coefficients between the measurement variables were positive, indicating that each connected factor was positively related.

The PLS path modelling may not able to demonstrate a global fit model (Hair et al. 2017; Chin 1998), so the model was statistically analyzed by using the Standardised Root Mean Square Residual (SRMR), where a value of less than 0.10 is considered as a statistically good model (Hair et al., 2017). Another measurement for the statistically fit model proposed in the SEM literature is the normed fit index (Bentler and Bonett, 1980). It computes the Chi-squared value of the hypothetical model by using the NFI. The NFI values were between 0 and 1 , where a value closer to 1 indicates a better fit of the model and values $>0.9$ indicates an acceptable fit of the model.

Table 2. The reliability of each measurement dimensions

\begin{tabular}{|l|l|l|l|l|}
\hline \multicolumn{1}{|c|}{ Latent variable } & \multicolumn{1}{|c|}{$\begin{array}{c}\text { Cronbach's } \\
\text { Alpha }\end{array}$} & $\begin{array}{c}\text { Cronbach's } \\
\text { Alpha if Item } \\
\text { Deleted }\end{array}$ & \multicolumn{1}{|c|}{$\begin{array}{c}\text { Composite } \\
\text { Reliability }\end{array}$} & $\begin{array}{c}\text { Average Variance } \\
\text { Extracted }\end{array}$ \\
\hline Learning Motivation (LM) & 0.835 & 0.889 & 0.911 & 0.671 \\
\hline Self-Directed Learning (SDL) & 0.725 & 0.911 & 0.822 & 0.481 \\
\hline Technology Readiness (TRD) & 0.758 & 0.905 & 0.777 & 0.538 \\
\hline Social Presence (SP) & 0.794 & 0.897 & 0.839 & 0.568 \\
\hline Teaching Presence (TP) & 0.825 & 0.891 & 0.848 & 0.651 \\
\hline
\end{tabular}


Table 3. The Principal factor analysis

\begin{tabular}{|c|c|c|}
\hline Latent Variable & Items for Each Variable & Factor loadings \\
\hline \multirow[t]{5}{*}{ Learning Motivation (LM) } & LM1 & .669 \\
\hline & LM2 & .677 \\
\hline & LM3 & .677 \\
\hline & LM4 & .620 \\
\hline & LM5 & .685 \\
\hline \multirow[t]{5}{*}{ Self-Directed Learning (SDL) } & $\mathrm{SD} 2$ & .783 \\
\hline & SD3 & .808 \\
\hline & SD4 & .631 \\
\hline & SD5 & .647 \\
\hline & SD8 & .654 \\
\hline \multirow[t]{3}{*}{ Technology Readiness (TRD) } & TRD1 & .705 \\
\hline & TRD2 & .687 \\
\hline & TRD3 & .603 \\
\hline \multirow[t]{4}{*}{ Social Presence (SP) } & SP2 & .778 \\
\hline & SP4 & .683 \\
\hline & SP6 & .675 \\
\hline & TP5 & .600 \\
\hline \multirow[t]{3}{*}{ Teaching Presence (TP) } & TP1 & .633 \\
\hline & TP2 & .613 \\
\hline & CP7 & .623 \\
\hline
\end{tabular}

Table 4. Correlation between each measurement dimensions

\begin{tabular}{|l|l|l|l|l|}
\hline & \multicolumn{1}{|c|}{$\begin{array}{c}\text { Learning } \\
\text { motivation } \\
(\mathbf{L M})\end{array}$} & $\begin{array}{c}\text { Self-directed } \\
\text { learning } \\
\text { readiness } \\
\text { (SDL) }\end{array}$ & $\begin{array}{c}\text { Social presence } \\
\text { (SP) }\end{array}$ & $\begin{array}{c}\text { Teaching } \\
\text { presence (TP) }\end{array}$ \\
\hline Self-directed learning (SDL) & $0.666^{* *}$ & & & \\
\hline Social presence (SP) & $0.735^{* *}$ & $0.634^{* *}$ & & \\
\hline Teaching presence (TP) & $0.759^{* *}$ & $0.648^{* *}$ & $0.772^{* *}$ & \\
\hline Technology readiness (TRD) & $0.729^{* *}$ & $0.627^{* *}$ & $0.634^{* *}$ & $0.681^{* *}$ \\
\hline
\end{tabular}

${ }^{* *}$ Correlation is significant at 0.01 level (2-tailed)

\subsection{Summary of Hypotheses}

This study presented several major constructs of the research model, including the learning motivation, self-directed learning, technology readiness, social presence, teaching presence. The definition of each construct is summarized in Table 8 .

The summary of the hypothesised relationships is shown in Table 9. Although the social presence was not included in the model, most of the hypotheses were justified. 
Journal of Organizational and End User Computing

Volume 33 •Issue 6 • November-December 2021

Table 5. Statistics of 5 measurement variables

\begin{tabular}{|l|l|l|}
\hline & \multicolumn{1}{|c|}{ Mean Score } & \multicolumn{1}{c|}{ S.D. } \\
\hline Learning motivation & 3.51 & 0.812 \\
\hline Self-directed learning & 3.31 & 0.742 \\
\hline Technology readiness & 3.59 & 0.801 \\
\hline Social presence & 3.29 & 0.809 \\
\hline Teaching presence & 3.50 & 0.794 \\
\hline
\end{tabular}

Table 6. Statistical comparison of gender group mean score

\begin{tabular}{|c|c|c|c|c|c|}
\hline \multirow{2}{*}{ Variable } & \multicolumn{2}{|c|}{ Mean } & \multirow{2}{*}{$\begin{array}{c}\text { Mean } \\
\text { Difference. }\end{array}$} & \multirow{2}{*}{$F$-value } & \multirow{2}{*}{$p$-value } \\
\hline & Male & Female & & & \\
\hline Self-directed learning & 3.30 & 3.33 & 0.269 & 5.13 & 0.729 \\
\hline Technology readiness & 3.50 & 3.67 & 0.165 & 11.00 & $0.049^{*}$ \\
\hline Social presence & 3.24 & 3.34 & 0.965 & 1.75 & 0.262 \\
\hline Teaching presence & 3.42 & 3.57 & 0.149 & 3.68 & 0.074 \\
\hline Learning motivation & 3.42 & 3.59 & 0.168 & 4.74 & $0.047 *$ \\
\hline
\end{tabular}

Figure 2. PLS result

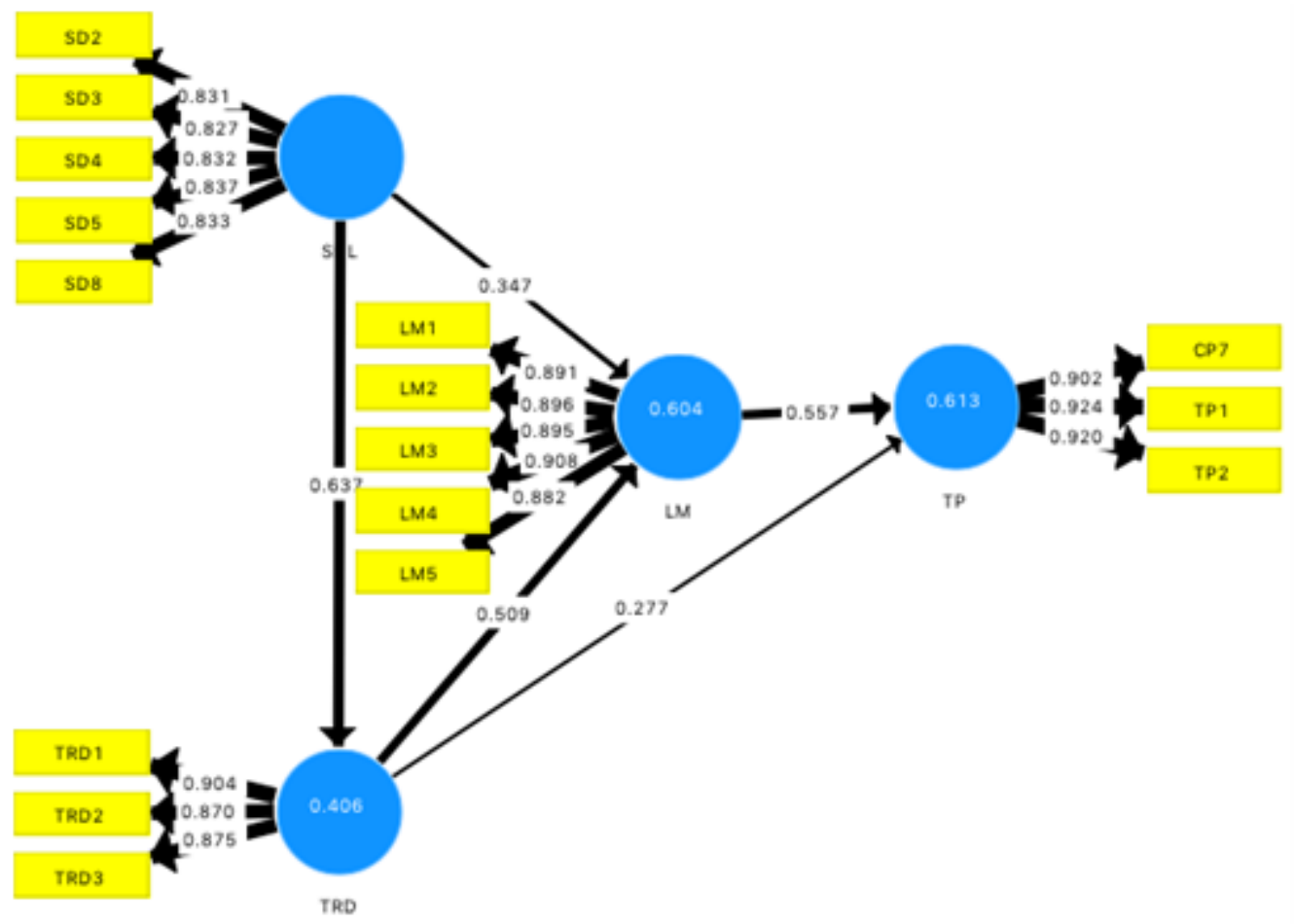


Figure 3. The research model based on the PLS result

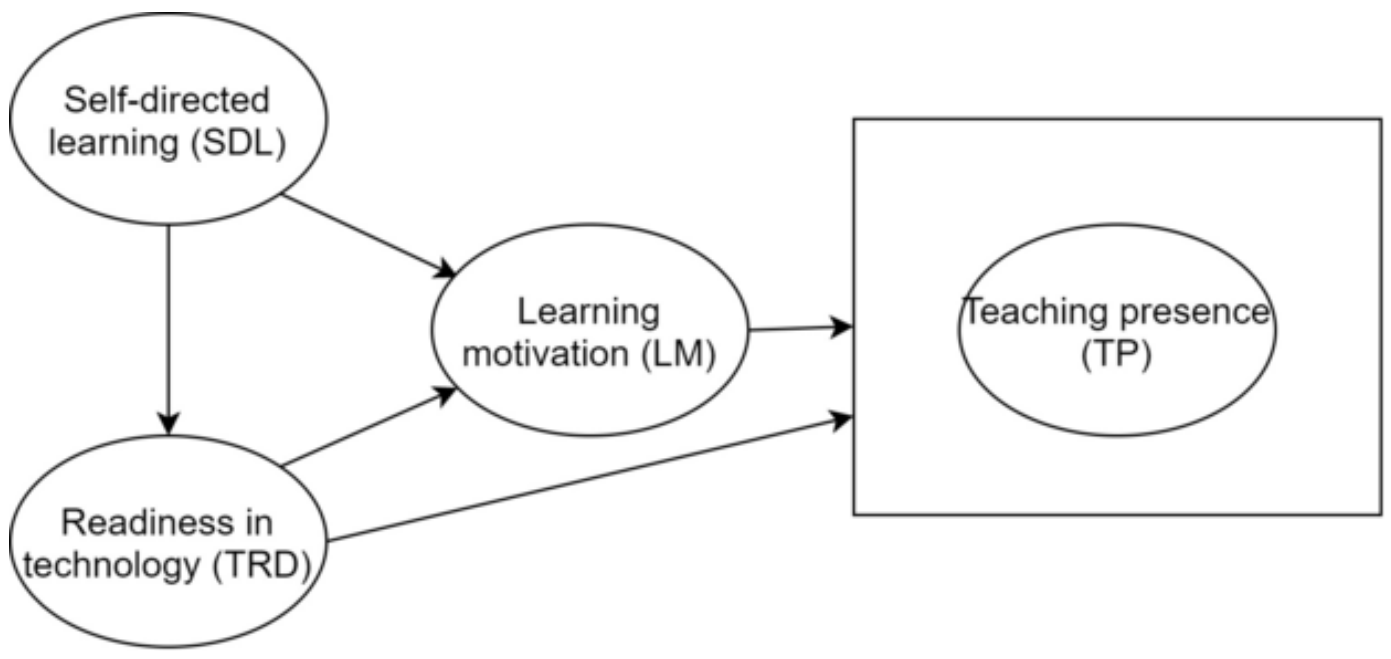

Table 7. Structural path coefficients

\begin{tabular}{|l|l|l|l|l|l|l|}
\hline & \multicolumn{3}{|c|}{ Teaching presence (T.P.) } & \multicolumn{3}{c|}{ Learning motivation (L.M.) } \\
\hline & \multicolumn{1}{|c|}{ Direct } & Indirect & Total effect & \multicolumn{1}{c|}{ Direct } & Indirect & Total effect \\
\hline $\begin{array}{l}\text { Learning motivation } \\
\text { (L.M.) }\end{array}$ & $0.557 * * *$ & & 0.557 & & & \\
\hline $\begin{array}{l}\text { Self-directed learning } \\
\text { readiness (S.D.L.) }\end{array}$ & & $0.551 * *$ & 0.551 & $0.347 * * *$ & $0.324 * *$ & 0.671 \\
\hline $\begin{array}{l}\text { Technology readiness } \\
\text { (T.R.D.) }\end{array}$ & $0.277 * * *$ & $0.284 * *$ & 0.561 & $0.509 *$ & & 0.509 \\
\hline
\end{tabular}

Table 8. Summary on the definitions of the research items

\begin{tabular}{|l|l|}
\hline \multicolumn{1}{|c|}{ Items } & \multicolumn{1}{c|}{ Definition } \\
\hline Learning Motivation (LM) & $\begin{array}{l}\text { Students' learning motivation and a willingness to participate and interact in } \\
\text { class }\end{array}$ \\
\hline Self-Directed Learning (SDL) & $\begin{array}{l}\text { Students' intention to direct themselves to understand the knowledge and to set } \\
\text { goals. }\end{array}$ \\
\hline Technology Readiness (TRD) & $\begin{array}{l}\text { Students' abilities in effective individual and group communication, access and } \\
\text { sharing of materials, etc. using technologies. }\end{array}$ \\
\hline Social Presence (SP) & Learners' social and emotional behaviour in classes. \\
\hline Teaching Presence (TP) & The drives of students to actively think and engage. \\
\hline
\end{tabular}


Table 9. Hypotheses testing results

\begin{tabular}{|l|l|}
\hline \multicolumn{1}{|c|}{ Hypotheses } & \\
\hline H1. Self-directed learning (SDL) positively impacts on the perception of learning presences & \\
\hline H1a. Self-directed learning (SDL) positively impacts on the teaching presence & justified \\
\hline H1b. Self-directed learning (SDL) positively impacts on the social presence & Not justified \\
\hline H2. Self-directed learning (SDL) positively impacts on the learning motivation & Justified \\
\hline $\begin{array}{l}\text { H3. Technology readiness (TRD) of students positively impacts the perception of learning } \\
\text { presence }\end{array}$ & \\
\hline H3a. Technology readiness positively impacts on the teaching presence & Justified \\
\hline H3b. Technology readiness positively impacts on the social presence & Not justified \\
\hline H4. Technology readiness (TRD) of students positively influences the learning motivation (LM) & Justified \\
\hline H5. Learning motivation (LM) of students positively impacts on the learning presences & \\
\hline H5a. Learning motivation positively impacts on the teaching presence & Justified \\
\hline H5b. Learning motivation positively impacts on the social presence & Not justified \\
\hline
\end{tabular}

\section{DISCUSSION}

The structural model reveals the interrelationships between the learning attributes and the learning presence (teaching). Based on the statistical analysis, it is shown that self-directed learning, learning motivation, and technology readiness are critical in determining online learning success and have an important implication on how online learning can be further enhanced for different purposes in educational settings. However, social presence was not affected by learning motivation, self-directed learning, and technology. Instead, it is argued that social presence is usually influenced by other factors such as media characteristics, income, synchronicity, participant experience, etc. (Handke et al, 2018).

\subsection{The Teaching Presence}

From the hypothetical model in Figure 2, learning motivation positively enhances teaching presence. Therefore, H5 is justified. In the online setting, which is supported by learning technologies, and the roles of the instructors are suppressed by the advanced learning features provided in the online learning platform. Thus, the effects of teaching presence were weakened in the perception of learning.

The results from the PLS model reveal that social presence does not participate in the model, while teaching presence does. Therefore, $\mathrm{H} 1 \mathrm{~b}$ and $\mathrm{H} 3 \mathrm{~b}$ are not justified. This can be explained that the online learning situation has substituted the physical presence of teachers, and students perceived a sufficient amount of teaching presence under the technology-supported learning environment. In other words, the existence of social presence does not significantly contribute to learning motivation.

\subsection{Attributes Determining Learning Effectiveness}

\subsubsection{Self-Directed Learning, Learning Motivation, and Readiness of Technology}

The results suggest that the SDL, TRD, and LM are crucial to the learning effectiveness and TP. Therefore, H1, H3, and H5 are justified. SDL and TRD are critical pre-requisites for motivating students to learn. 


\subsubsection{Learning Motivation and Teaching Presence}

The learning motivation (LM) significantly affects the perceived teaching presence (TP), with a direct effect of 0.557 , while LM is also affected by SDL and TRD. The results imply that both SDL and TRD contribute to LM, which in return, impacts the perceived teaching presence (TP).

\subsubsection{Technology Readiness and Teaching Presence}

It is also interesting to see from the results that technology readiness imposes a significant and robust effect on teaching presence (TP), alongside its impact on learning motivation (LM). Online learning is much relevant on technology-enhanced facilitation, with which students could have the sense of the teaching presence.

\subsection{Technologies for Education Industry}

Due to the COVID-19 pandemic, the mode of e-learning has undergone a new revolution with the use of virtual reality (Tang et al., 2021), mixed reality (Tang et al., 2018; 2020), as well as other latest technologies for teaching and learning. Further, the development of tools to facilitate communication, sharing, and management is also important to the education sector. For instance, recent blockchain technology can be used for authentication and authorization of a system (Esposito et al., 2021) and enhance the traceability and trackability of the system to enhance management (Ho et al., 2021). On the other hand, other advanced technologies such as the IoT-based system and cloud computing can be used for data processing and providing and sharing of teaching materials and management (AlQerem et al., 2020; Youssef et al., 2018). Furthermore, the latest AI technology can be used for data mining (Li et al., 2019) to investigate student learning patterns to determine the appropriate teaching pedagogy to students participating in e-learning.

\section{CONCLUSIONS}

This study revealed the impacts of online learning effectiveness based on self-directed learning, technology readiness, and students' learning motivation. Despite the impacts of various factors being widely studied, student readiness in motivating e-learning motivation and perception, particularly in a synchronous mode of teaching, is still in its infancy. This study adds value to the intervention of discovering how the individual self-directed learning affects technology readiness so as to affect their learning motivation and studying perceptions. This study also investigated the effects of technology in student learning under the COVID-19 pandemic by investigating the path models among various e-learning factors.

In summary, synchronous learning is a plausible arrangement under exceptional circumstances during the pandemic. According to our study, to ensure effective learning, both students' selfdirectedness and technology readiness are crucial and are the most significant actors in learning motivation. The existence of social presence in the online learning setting may not be the key actor in driving students to learn proactively, whereas the teaching presence, as perceived by students, does significantly. The experience of offering online courses on such a 'blanket' scale is unprecedented. Though our study may not yet be large enough for conclusive evidence, the results provide important insights for online course developers or educators on what and how to put together an online course.

\subsection{Implications of the Study}

The research investigated student perception of self-directed learning and their readiness in computer technology to support synchronous learning that is important to synchronous learning. It was revealed that students' self-directed learning and their technology readiness positively influence their perception of synchronous learning. Unlike regular FTF learning, students have to have the initiative to participate in online classes and adopt the latest computer technologies to assist in distance learning. Therefore, 
this research has important implications not only in providing fundamental research in synchronous supported learning by determining the roles of self-directed learning and technology readiness, but is also important in determining future research directions for the successful implementation of future synchronous learning. In the emerging internet of things (IoT) era, it is still important to further investigate the essential computer-assisted technologies, especially using mobile and IoT devices, to promote student learning effectively online. On the other hand, more studies should be focused on the design and settings of such technologies and investigate the underlying features and functions provided by the computer technology for effective synchronous learning should be conducted in the future.

\subsection{Significance of the Study}

This study investigated how the students' behavioural factors during the pandemic affect their learning perception. The results have revealed that self-directed learning is important to affect their learning motivation and technology readiness. On the other hand, the factors affect teaching presence of their learning attitudes, while there is no significance in students' social presence in synchronous learning.

Therefore, the current investigation has important practical and managerial significance in explaining the existence of a relationship between variables and the real world. It arises from the result that selfdirected learning is very important to once learning motivation and their readiness to adopt the latest online learning technologies for learning so as to affect their learning attitudes. It is due to the fact that online learning is difficult to be monitored by educators and encourage by peers. The results have revealed that encourage once self-learning is particularly important. Nevertheless, self-directed learning may not able to encourage once communication. Educators may need to consider other teaching pedagogies such as group-based learning and presentation to enhance their social presence managerially.

In practice, more actions should be taken in the future to encourage once self-directed learning. On the other hand, enhancing communications and connections between educators and peers during classes such as encouraging students to facilitate students' self-directed learning requires students to collaborate in group projects to encourage them to participate in social connections are important practically and managerially in a synchronous mode of teaching.

\subsection{Limitation of the Study}

The sample size in the current study was not large due to the limited number of online students amid the pandemic arrangements adopted at the pandemic outbreak. On the other hand, this is the first attempt for colleagues and universities to implement synchronous learning and limitations of resources, so additional information such as students' system statistics is not included in this study. We expect to further enhance the research for a long data collection period and to integrate students from different regions.

\section{ETHICAL STATEMENT}

Approval was obtained from the ethics committee of the University. The procedures used in this study adhere to the tenets of the Declaration of Helsinki.

\section{CONSENT STATEMENT}

Informed consent was obtained from all individual participants included in the study.

\section{ACKNOWLEDGEMENT}

The authors would like to acknowledge the support of the Macau Higher Education Fund (Ref.: TET CITYU-2020-04) for this research. 


\section{REFERENCES}

Ajzen, I. (1991). The theory of planned behavior. Organizational Behavior and Human Decision Processes, 50(2), 179-211. doi:10.1016/0749-5978(91)90020-T

Al-Qerem, A., Alauthman, M., \& Almomani, A. (2011). Social presence within the community of inquiry framework. International Review of Research in Open and Distance Learning, 12(5), 40-56. doi:10.19173/ irrodl.v12i5.924

Aleem, M., Qurat-ul-Ain, Q.-A., Shahid, F., Islam, M. A., Iqbal, M. A., \& Yousaf, M. M. (2019). A Review of Technological Tools in Teaching and Learning Computer Science. Eurasia Journal of Mathematics, Science and Technology Education, 15(11), em1773. doi:10.29333/ejmste/109611

Amirkhanova, K., Ageeva, A., \& Fakhretdinov, R. (2016). Enhancing Students' Learning Motivation through Reflective Journal Writing. 10.15405/epsbs.2016.07.3

Arbaugh, J. B., Cleveland-Innes, M., Diaz, S. R., Garrison, D. R., Ice, P., Richardson, J. C., \& Swan, K. P. (2008). Developing a community of inquiry instrument: Testing a measure of the community of inquiry framework using a multi-institutional sample. The Internet and Higher Education, 11(3-4), 133-136. doi:10.1016/j. iheduc.2008.06.003

Archibald, D. (2010). Fostering the development of cognitive presence: Initial findings using the community of inquiry survey instrument. Internet \& Higher Education, 13(1-2), 73-74. doi:10.1016/j.iheduc.2009.10.001

Baig, M. (2011). A Critical Study Of Effectiveness Of Online Learning On Students Achievement. $i$-Manager's Journal of Educational Technology, 7(4). .10.26634/jet.7.4.1391

Bentler, P. M., \& Bonett, D. G. (1980). Significance Tests and Goodness-of-Fit in the Analysis of Covariance Structures. Psychological Bulletin, 88(3), 588-600. doi:10.1037/0033-2909.88.3.588

Boelens, R., De Wever, B., \& Voet, M. (2017). Four key challenges to the design of blended learning: A systematic literature review. Educational Research Review, 22, 1-18. doi:10.1016/j.edurev.2017.06.001

Bolsen, T., Evans, M., \& Fleming, A. M. (2016). A Comparison of Online and Face-to-Face Approaches to Teaching Introduction to American Government. Journal of Political Science Education, 12(3), 302-317. doi: 10.1080/15512169.2015.1090905

Broadbent, J. (2017). Comparing online and blended learner's self-regulated learning strategies and academic performance. The Internet and Higher Education, 33, 24-32. doi:10.1016/j.iheduc.2017.01.004

Bryant, L. C., Vincent, R., Shaqlaih, A., \& Moss, G. (2013). Behaviorism and behavioral learning theory. In B. J. Irby, G. Brown, R. Lara-Alecio, \& S. Jackson (Eds.), The handbook of educational theories (pp. 91-103). IAP Information Age Publishing.

Cheon, J., Lee, S., Crooks, S. M., \& Song, J. (2012). An investigation of mobile learning readiness in higher education based on the theory of planned behavior. Computers \& Education, 59(3), 1054-1064. doi:10.1016/j. compedu.2012.04.015

Chin, W. W. (1998). The partial least squares approach to structural equation modeling. Modern Methods for Business Research, 295(2), 295-336.

Compeau, D., \& Higgins, C. (1995). Computer self efficacy: Development of a measure and initial test. Management Information Systems Quarterly, 19(1), 9. doi:10.2307/249688

Esposito, C., Ficco, M., \& Gupta, B. B. (2021). Blockchain-based authentication and authorization for smart city applications. Information Processing \& Management, 58(2), 102468. doi:10.1016/j.ipm.2020.102468

Fahnoe, C., \& Mishra, P. (2013). Do 21st century learning environments support self-directed learning? Middle school students' response to an intentionally designed learning environment. In Society for Information Technology \& Teacher Education International Conference (pp. 3131-3139). Association for the Advancement of Computing in Education (AACE).

Fairchild, A. J., Jeanne-Horst, S., Finney, S. J., \& Barron, K. E. (2005). Evaluating existing and new validity evidence for the academic motivation scale. Contemporary Educational Psychology, 30(3), 331-358. 
Faisal, P., \& Kisman, Z. (2020). Information and communication technology utilization effectiveness in distance education systems. International Journal of Engineering Business Management, 12. Advance online publication. doi:10.1177/1847979020911872

Filgona, J., Sakiyo, J., Gwany, D. M., \& Okoronka, A. U. (2020). Motivation in Learning. Asian Journal of Education and Social Studies, 10(4), 16-37. doi:10.9734/ajess/2020/v10i430273

Findik, C., \& Ozkan, S. (2013). A model for instructors' adoption of learning management systems: Empirical validation in higher education context. The Turkish Online Journal of Educational Technology, 12(2), 13-25.

Francescucci, A., \& Rohani, L. (2019). Exclusively Synchronous Online (VIRI) Learning: The Impact on Student Performance and Engagement Outcomes. Journal of Marketing Education, 41(1), 60-69. doi: $10.1177 / 0273475318818864$

Fredricks, J. A., Blumenfeld, P. C., \& Paris, A. H. (2004). School engagement: Potential of the concept, state of the evidence. Review of Educational Research, 74(1), 59-109. doi:10.3102/00346543074001059

Garrison, D. R., \& Akyol, Z. (2013). Toward the development of a metacognition construct for communities of inquiry. The Internet and Higher Education, 24, 66-71. doi:10.1016/j.iheduc.2014.10.001

Garrison, D. R., \& Cleveland-Innes, M. (2005). Facilitating cognitive presence in online learning: Interaction is not enough. American Journal of Distance Education, 19(3), 133-148. doi:10.1207/s15389286ajde1903_2

Garrison, R., \& Kanuka, H. (2004). Blended learning: Uncovering its transformative potential in higher education. The Internet and Higher Education, 7(2), 95-105. doi:10.1016/j.iheduc.2004.02.001

Geng, S., Law, K. M. Y., \& Niu, B. (2019). Investigating self-directed learning and technology readiness in blending learning environment. Int J Educ Technol High Educ, 16(1), 17. doi:10.1186/s41239-019-0147-0

Gilbert, N., \& Driscoll, M. (2002). Collaborative knowledge building: A case study. Educational Technology Research and Development, 50(1), 59-79. doi:10.1007/BF02504961

Gulek, J. C., \& Demirtas, H. (2005). Learning with technology: The impact of laptop use on student achievement. The Journal of Technology, Learning, and Assessment, 3(2). http://www.jtla.org

Hair, J. F. Jr, Sarstedt, M., Ringle, C. M., \& Gudergan, S. P. (2017). Advanced issues in partial least squares structural equation modeling. Sage Publications.

Handke, L., Schulte, E. M., Schneider, K., \& Kauffeld, S. (2018). The medium isn't the message: Introducing a measure of adaptive virtual communication. Cogent Arts \& Humanities, 5(1), 1. doi:10.1080/23311983.201 8.1514953

Henseler, J., \& Sarstedt, M. (2013). Goodness-of-fit indices for partial least squares path modeling. Computational Statistics, 28(2), 1-16. doi:10.1007/s00180-012-0317-1

Ho, G. T. S., Tang, Y. M., Tsang, K. Y., Tang, V., \& Chau, K. Y. (2021). A Blockchain-Based System to Enhance Aircraft Parts Traceability and Trackability for Inventory Management. Expert Systems with Applications, 115101. Advance online publication. doi:10.1016/j.eswa.2021.115101

Holenko Dlab, M., Boticki, I., Hoic-Bozic, N., \& Looi, C. K. (2020). Exploring group interactions in synchronous mobile computer-supported learning activities. Computers \& Education, 146, 103735. doi:10.1016/j. compedu.2019.103735

Hong, C., Hwang, M., Liu, H., \& Chen. (2014). Using a “prediction-observation explanation” inquiry model to enhance student interest and intention to continue science learning predicted by their internet cognitive failure. Computers \& Education, 72, 110-120.

Horton, W. (2006). E-learning by design. Pfeiffer.

Hrastinski, S. (2008). Asynchronous and synchronous e-learning. EDUCAUSE Quarterly, 4.

Hwang, A., \& Arbaugh, J. B. (2006). Virtual and traditional feedback-seeking behaviors: Underlying competitive attitudes and consequent grade performance. Decision Sciences Journal of Innovative Education, 4(1), 1-28. doi:10.1111/j.1540-4609.2006.00099.x 
Jelfs, A., \& Richardson, J. T. E. (2013). The use of digital technologies across the adult life span in distance education. British Journal of Educational Technology, 44(2), 338-351. doi:10.1111/j.1467-8535.2012.01308.x

Ke, F. (2010). Examining online teaching, cognitive, and social presence for adult students. Computers \& Education, 55(2), 808-820. doi:10.1016/j.compedu.2010.03.013

Khalid, M., Bashir, S., \& Amin, H. (2020). Relationship between Self-Directed Learning (SDL) and Academic Achievement of University Students: A Case of Online Distance Learning and Traditional Universities. Bulletin of Education and Research, 42(2), 131-148.

Kim, R., \& Song, H. D. (2021). Examining the Influence of Teaching Presence and Task-Technology Fit on Continuance Intention to Use MOOCs. Asia-Pacific Edu Res. doi:10.1007/s40299-021-00581-x

Kizilcec, R. F., Pérez-Sanagustín, M., \& Maldonado, J. J. (2017). Self-regulated learning strategies predict learner behavior and goal attainment in massive open online courses. Computers \& Education, 104, 18-33. doi:10.1016/j.compedu.2016.10.001

Kusuma, S., \& Viswanath, D. K. (2018). IOT And Big Data Analytics In E-Learning: A Technological Perspective and Review. IACSIT International Journal of Engineering and Technology, 7(1.8), 164. doi:10.14419/ijet. v7i1.8.11540

Law, K. M. (2019). Teaching project management using project-action learning (PAL) games: A case involving engineering management students in Hong Kong. International Journal of Engineering Business Management, 11, 1-7. doi:10.1177/1847979019828570

Law, K. M., \& Breznik, K. (2017). Impacts of innovativeness and attitude on entrepreneurial intention: Among engineering and non-engineering students. International Journal of Technology and Design Education, 27(4), 683-700. doi:10.1007/s10798-016-9373-0

Law, K. M., Lee, V. C., \& Yu, Y. T. (2010). Learning motivation in e-learning facilitated computer programming courses. Computers \& Education, 55(1), 218-228. doi:10.1016/j.compedu.2010.01.007

Law, K. M. Y., Geng, S., \& Li, T. (2019). Student enrollment, motivation and learning performance in a blended learning environment: The mediating effects of social, teaching, and cognitive presence. Computers \& Education, 136(1), 1-12. doi:10.1016/j.compedu.2019.02.021

Lee, C. B., \& Teo, T. (2010). Fostering self-directed learning with ICT. In C. S. Chai \& Q. Wang (Eds.), ICT for self-directed and collaborative learning (pp. 39-51). Pearson.

Lee, K., Tsai, P. S., Chai, C. S., \& Koh, J. H. L. (2014). Students' perceptions of self-directed learning and collaborative learning with and without technology. Journal of Computer Assisted Learning, 30(5), 425-437. doi:10.1111/jcal.12055

Li, D., Deng, L. B., Gupta, B. B., Wang, H. X., \& Choi, C. (2019). A novel CNN based security guaranteed image watermarking generation scenario for smart city applications. Information Sciences, 479, 432-447. doi:10.1016/j.ins.2018.02.060

Liu, Y., Li, H., \& Carlsson, C. (2010). Factors driving the adoption of m-learning: An empirical study. Computers \& Education, 55(3), 1211-1219. doi:10.1016/j.compedu.2010.05.018

Liu, Y.-C., Lu, S.-J., Kao, C.-Y., Chung, L., \& Tan, K. H. (2019). Comparison of AR and physical experiential learning environment in supporting product innovation. International Journal of Engineering Business Management, 11. Advance online publication. doi:10.1177/1847979019839578

Martin, F., \& Parker, M. (2014). Use of Synchronous Virtual Classrooms: Why, Who and How? Journal of Online Learning and Teaching, 10(2), 192-210.

Mehri, M., \& Uplane, M. (2015). Synchronous and asynchronous e-learning styles and academic performance of e-learners. Procedia: Social and Behavioral Sciences, 176, 129-138. doi:10.1016/j.sbspro.2015.01.453

Milligan, C., \& Littlejohn, A. (2014). Supporting professional learning in a massive open online course. The International Review of Research in Open and Distributed Learning, 15(5). Advance online publication. doi:10.19173/irrodl.v15i5.1855 
Mo, J. P. T., \& Tang, Y. M. (2017). Project-based learning of systems engineering V model with the support of 3D printing. Australasian Journal of Engineering Education, 22(1), 1, 3-13. doi:10.1080/22054952.2017.1338229

Moftakhari, M. M. (2013). Evaluating e-learning readiness of faculty of letters of Hacettepe (Master Thesis). Ankara: Hacettepe University.

Mtebe, J. S., \& Raisamo, R. (2014). Challenges and instructors' intention to adopt and use open educational resources in higher education in Tanzania. International Review of Research in Open and Distance Learning, 15(1), 249-271. doi:10.19173/irrodl.v15i1.1687

Ni, A. Y. (2013). Comparing the Effectiveness of Classroom and Online Learning: Teaching Research Methods. Journal of Public Affairs Education, 19(2), 199-215. doi:10.1080/15236803.2013.12001730

Parasuraman, A. (2000). Technology Readiness Index (TRI) a multiple-item scale to measure readiness to embrace new technologies. Journal of Service Research, 2(4), 307-320. doi:10.1177/109467050024001

Parasuraman, A., \& Colby, C. L. (2015). An updated and streamlined technology readiness index: TRI 2.0. Journal of Service Research, 18(1), 59-74. doi:10.1177/1094670514539730

Pervez, S., Rehman, S. u., \& Gasim, D. (2018). Role of Internet of Things (IoT). Higher Education.

Phalaunnaphat, S. (2015). Developing Students' Learning Ability by Dint of Self-Directed Learning. Procedia: Social and Behavioral Sciences, 197, 2074-2079. doi:10.1016/j.sbspro.2015.07.577

Piskurich, G. M. (2003). Preparing learners for e-learning. John Wiley \& Sons.

Porter, W. W., Graham, C. R., Bodily, R. G., \& Sandberg, D. S. (2016). A qualitative analysis of institutional drivers and barriers to blended learning adoption in higher education. The internet and Higher education, 28 , 17-27. doi:10.1016/j.iheduc.2015.08.003

Richardson, J. C., Arbaugh, J. B., Cleveland-Innes, M., Ice, P., Swan, K. P., \& Garrison, D. R. (2012). Using the Community of Inquiry Framework to Inform Effective Instructional Design. In L. Moller \& J. Huett (Eds.), The Next Generation of Distance Education. Springer. doi:10.1007/978-1-4614-1785-9_7

Riswanto, A., \& Aryani, S. (2017). Learning motivation and student achievement: Description analysis and relationships both. COUNS-EDU. The International Journal of Counseling and Education., $2(1), 42$. doi: $10.23916 / 002017026010$

Rovai, A. P., \& Jordan, H. (2004). Blended learning and sense of community: A comparative analysis with traditional and fully online graduate courses. The International Review of Research in Open and Distributed Learning, 5(2). Advance online publication. doi:10.19173/irrodl.v5i2.192

Sana, F., Weston, T., \& Cepeda, N. J. (2013). Laptop multitasking hinders classroom learning for both users and nearby peers. Computers \& Education, 62, 24-31.

Sanchez, G. (2013). PLS path modeling with R. Berkeley, CA: Trowchez Editions.

Shea, P., Hayes, S., Vickers, J., Gozza-Cohen, M., Uzuner, S., \& Mehta, R. (2010). A re-examination of the community of inquiry framework: Social network and content. Academic Press.

Short, J., Williams, E., \& Christie, B. (1976). The social psychology of telecommunications. John Wiley \& Sons.

Tabor, S. (2007). Narrowing the distance: Implementing a hybrid learning model for information security education. Quarterly Review of Distance Education, 8(1), 47-57.

Tan, C. (2021). The impact of COVID-19 on student motivation, community of inquiry and learning performance. Asian Education and Development Studies, 10(2), 308-321. doi:10.1108/AEDS-05-2020-0084

Tang, Y. M., Au, K. M., Lau, H. C. W., Ho, G. T. S., \& Wu, C. H. (2020). Evaluating the effectiveness of learning design with mixed reality (MR) in higher education. Virtual Reality (Waltham Cross), 24(4), $797-807$. doi:10.1007/s10055-020-00427-9

Tang, Y. M., Au, K. M., \& Leung, Y. (2018). Comprehending products with mixed reality: Geometric relationships and creativity. International Journal of Engineering Business Management, 10. Advance online publication. doi:10.1177/1847979018809599 
Tang, Y. M., Chen, P. C., Law, K. M. Y., Wu, C. H., Lau, Y. Y., Guan, J., He, D., \& Ho, G. T. S. (2021). Comparative analysis of Student's live online learning readiness during the coronavirus (COVID-19) pandemic in the higher education sector. Computers \& Education, 168, 104211. doi:10.1016/j.compedu.2021.104211 PMID:33879955

Tang, Y. M., Ng, G. W. Y., Chia, N. H., So, E. H. K., Wu, C. H., \& Ip, W. H. (2021). Application of virtual reality (VR) technology for medical practitioners in type and screen (T\&S) training. Journal of Computer Assisted Learning, 37(2), 359-369. doi:10.1111/jcal.12494

Tang, Y. M., \& Yu, K. M. (2018). Development and evaluation of a mobile platform for teaching mathematics of CAD subjects. Computer-Aided Design and Applications, 15(2), 164-169. doi:10.1080/16864360.2017.1375665

Teo, T., Tan, S. C., Lee, C. B., Chai, C. S., Koh, J. H. L., Chen, W. L., \& Cheah, H. M. (2010). The self-directed learning with technology scale (SDLTS) for young students: An initial development and validation. Computers \& Education, 55(4), 1764-1771. doi:10.1016/j.compedu.2010.08.001

Tullis, J. G., \& Benjamin, A. S. (2011). On the effectiveness of self-paced learning. Journal of Memory and Language, 64(2), 109-118. doi:10.1016/j.jml.2010.11.002 PMID:21516194

Vanslambrouck, S., Zhu, C., Lombaerts, K., Philipsen, B., \& Tondeur, J. (2018). Students' motivation and subjective task value of participating in online and blended learning environments. The Internet and Higher Education, 36, 33-40. doi:10.1016/j.iheduc.2017.09.002

Vaughan, N. (2007). Perspectives on blended learning in higher education. International Journal on E-Learning, $6(1), 81-94$.

Wang, Y., Wu, M., \& Wang, H. (2009). Investigating the determinants and age and gender differences in the acceptance of mobile learning. British Journal of Educational Technology, 40(1), 92-118. doi:10.1111/j.14678535.2007.00809.x

Wei, C. W., Chen, N. S., \& Kinshuk, . (2012). A model for social presence in online classrooms. Educational Technology Research and Development, 60(3), 529-545. doi:10.1007/s11423-012-9234-9

Yilmaz, R. (2016). Knowledge sharing behaviors in e-learning community: Exploring the role of academic self-efficacy and sense of community. Computers in Human Behavior, 63, 373-382.

You, H. (2019). Students' Perception about Learning using MOOC. International Journal Of Emerging Technologies In Learning, 14(18), 203-208. doi:10.3991/ijet.v14i18.10802

Youssef, F., El Habib, B. L., Hamza, R., Ahmed, E., \& Hanoune, M. (2018). A New Conception of Load Balancing in Cloud Computing Using Tasks Classification Levels. International Journal of Cloud Applications and Computing, 8(4), 118-133. doi:10.4018/IJCAC.2018100107

Zimmerman, B. J. (2000). Attaining self-regulation: A social-cognitive perspective. In M. Boekaerts, P. R. Pintrich, \& M. Zeidner (Eds.), Handbook of self-regulation (pp. 13-39). Academic Press. doi:10.1016/B978012109890-2/50031-7 
Ka Yin Chau is currently the Associate Dean in Faculty of Business, City University of Macau. He is a Chartered Engineer (CEng), Six Sigma Master Black Belt (MBB) together with his Bachelor, Master and Doctoral degrees awarded from the UK and Australia respectively. Dr. Chau has more than 15 years of industry experiences in Mainland China, Hong Kong, and the USA. His research interests are Services Quality Management, Consumer Behaviour and Operations Management. He has published more than 50 articles in major international academic journals.

Kris Law holds a Ph.D in Organizational Learning and an M.Phil. in Machining Processes, both obtained from the City University of Hong Kong. Upon her Ph.D graduation, she undertook a post-doctoral research scholarship at the Graduate Institute of Industrial Engineering, National Taiwan University on a regional high-tech industry study. Her expertise lies in Organizational Learning and Development (OLD), Technological Innovation and Entrepreneurship (TIE), Engineering Education, and Smart Industrial Initiatives (SII).

Yuk Ming Tang received his B.Sc. and M.Phil. from The Chinese University of Hong Kong. He was awarded a Ph.D. degree from the same university. He worked as a postdoctoral fellow at the Faculty of Medicine at CUHK after graduation. Currently, he is teaching in the Department of Industrial and Systems Engineering, the Hong Kong Polytechnic University (PolyU). His research interests include virtual reality (VR)/ mixed reality (MR), artificial intelligence (AI), blockchain technology, computer-aided design (CAD) in Industry 4.0 and healthcare applications. $\mathrm{He}$ is the corresponding author of this paper. 